\title{
REVIEW
}

\section{New light on Myc and Myb. Part I. Myc}

\author{
Bernhard Lüscher and Robert N. Eisenman
}

Division of Basic Sciences, Fred Hutchinson Cancer Research Center, Seattle Washington 98104 USA

The group of proto-oncogenes found to encode nuclear proteins now includes myc, myb, fos, jun, ski, cbl, erbA, members of the ets family, and possibly several others. Given that so many cytoplasmic and membrane-associated oncoproteins are involved in signal transduction pathways, one rather appealing notion has been that some or all of the nuclear oncoproteins encoded by these genes might act to mediate specific transcriptional responses to signals originally generated in the plasma membrane or cytoplasm (for review, see Weinberg 1989). During the last several years, a number of these oncoproteins, including ErbA, Fos, Jun and, most recently, Ets, have been demonstrated to be directly involved in transcriptional regulation. It is somewhat ironic that Myc and Myb, two of the first oncoproteins to be shown localized to the nucleus, have appeared to elude functional characterization. However, recent evidence has demonstrated that Myb also functions in transcription and, while Myc has remained a citadel of incomprehensibility, new studies have begun to bring this mysterious protein into sharper focus. At first glance, Myc and Myb would appear to have little in common, aside from the fact that both are predominantly localized in the nucleus. They are quite different structurally and their patterns of expression are also rather distinct, with Myc present in nearly all cell types while Myb is restricted to hematopoietic cells. However, the functions of both of these oncoproteins appear to be linked to proliferation, and these oncoproteins clearly play major roles in cell differentiation. Furthermore, recent work has cast some new light on both oncoproteins, and in what follows we attempt to meld older with more recent evidence relating to possible functions. This review will appear in two segments. In part I we consider studies relating to the structure and potential function of $\mathrm{Myc}_{\text {; }}$ part II, to appear in the next issue, will discuss recent findings on Myb.

Despite over 2700 publications listed by Medline relating to Myc family genes, there is still no strong consensus as to their molecular function. Although it is fashionable to say that we know nothing important about Myc, there is compelling evidence for the involvement of Myc in cell proliferation, mitogenesis, and differentiation (for reviews, see Cole 1986; Cory 1986; Penn et al. 1990a), as well as a large body of information concerning oncogenic activation and the intricacies of regulation of Myc expression (for review, see Spencer and Groudine 1990). However, we still lack direct evidence for the molecular function of Myc. Nonetheless, over the last few years two apparently competing models for Myc function have emerged and have received varying degrees of experimental support. These include a role in DNA replication and regulation of gene expression at transcriptional and post-transcriptional levels. We note that these models are competing in only the most superficial sense and that both viewpoints may be easily reconciled. In the following sections on Myc we will discuss these ideas for function in the context of recent developments defining the structure and characteristics of Myc proteins.

\section{Provocative interaction motifs}

Oddly enough, some of the most interesting insights into Myc function have come not so much from studies on Myc itself, but from recent work on other proteins that appear to possess limited structural similarities with Myc. These similarities fall into two classes: the helix-loop-helix (H-L-H) motif and the zipper motif. We will first briefly describe these motifs and then turn to their possible implications for Myc.

\section{$H-L-H$ proteins}

Among the proteins possessing limited structural homology with Myc are an important group of transcriptional regulators that have also been deeply implicated in the control of cell specification from humans to plants. These have been dubbed H-L-H proteins by virtue of their common structural motif (for recent reviews, see Jones 1990; Olson 1990). Some examples of the extent and types of sequence alignment are shown in Figure 1. No significant homologies among this group have been noted beyond the region indicated. At least superficially, these proteins have properties reminiscent of Myc family members in that most or all are localized in the nucleus and involved in cell-type determination. In addition, the genes encoding some of the H-L-H proteins (such as E2, Lyl-1, SCL/Tal) are situated at chromosomal breakpoints in human leukemias and, therefore, like the myc family, may be involved in the etiology of human cancers (Begley et al. 1989; Mellentin et al. 1989a,b; Chen et al. 1990).

Although it is interesting to find even limited homology between Myc protein family members and a widespread group of transcriptional activators, what makes this homology particularly fascinating is that it appears to correspond to a functionally important structural motif: two amphipathic $\alpha$-helices flanking a looped-out segment (together referred to as the H-L-H 


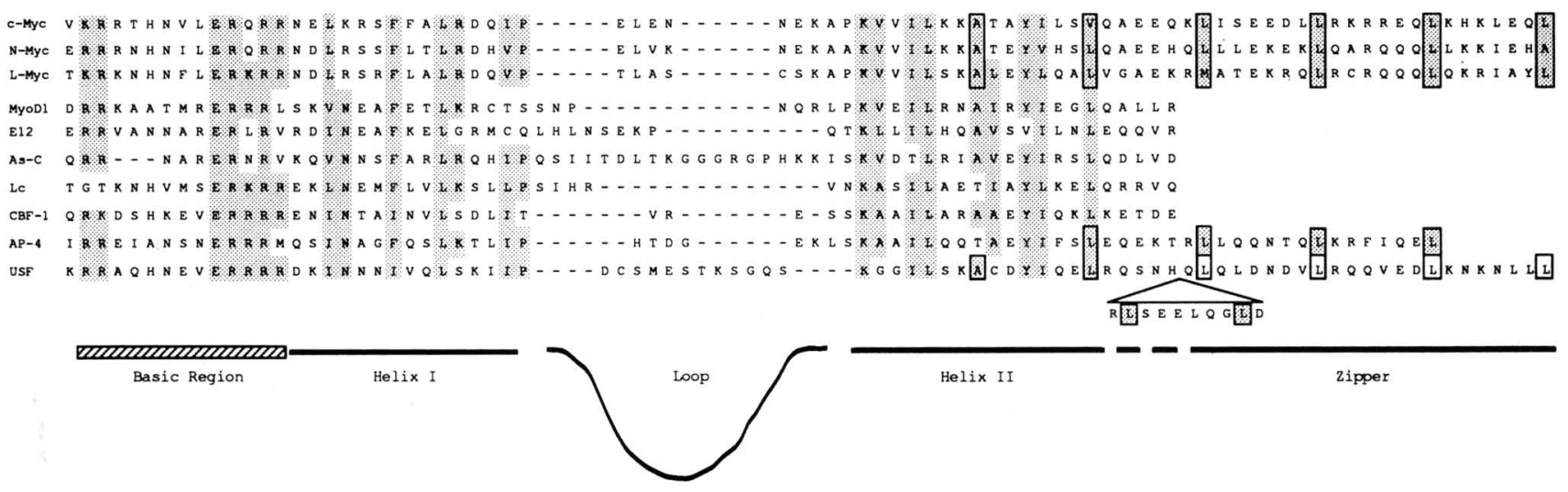

Figure 1. Comparison of BR-H-L-H and zipper domains among selected regulatory proteins in yeast, maize, Drosophila, mouse, and human, as well as the carboxyterminal regions of human c-Myc, N-Myc, and L-Myc proteins. Amino acid sequences are indicated in single-letter code. Identical or conserved amino acids that can be aligned between several species are shown as shaded areas in the $\mathrm{BR}-\mathrm{H}-\mathrm{L}-\mathrm{H}$ domain while the hydrophobic amino acid repeats in the zipper region are boxed. Note that the zipper and helix II domains in the Myc family proteins may represent one continuous helix with the hydrophobic spine of the zipper extending to include hydrophobic residues in helix II (shaded boxes). A similar situation appears to exist for AP-4. For USF the leucine repeat (open boxes) appears to be out of register with helix II while two other leucine residues (shaded boxes within insert) are in heptad phase with the hydrophobic residues in helix II. Amino acid sequences are from human c-Myc (Battey et al. 1983), human N-Myc (Kohl et al. 1986), human L-Myc (DePinho et al. 1987), MyoD1 (Davis et al. 1987), E12 (Murre et al. 1989a), Drosophila Achaete-scute (As-C), T4 (Villares and Cabrera 1987), maize Lc (Ludwig et al. 1989), Saccharomyces cerevisiae CBF-1 (Cai and Davis 1990), human AP-4 (Hu et al. 1990), and human USF (Gregor et al. 1990).

domain, $\mathrm{H}-\mathrm{L}-\mathrm{H}$ ) preceded by a basic region (BR) (see Fig. 1). The existence of the H-L-H is only inferred from the amino acid sequence. Both the segments surrounding the loop possess amino acid sequences that, when modeled with the appropriate periodicity, generate helices with well-conserved hydrophobic and charged surfaces (Murre et al. 1989a). The loop region more or less conforms to a category of protein structural elements, recently defined through a survey of X-ray-elucidated proteins which, in idealized form, resembles the Greek letter $\Omega$ (Leszczynski and Rose 1986).

There is now compelling evidence that the BR-H-L-H segment is a critical determinant of functionally relevant protein-protein and protein-DNA interactions. A great deal of recent work, well exemplified by studies on the MyoDl and E12/47 enhancer binding proteins (Lassar et al. 1989; Murre et al. 1989a,b; Davis et al. 1990), indicates that the homology region has a functionally bipartite structure with the H-L-H segment involved in homo- and heterotypic protein-protein interactions, while the basic regions are involved in DNA binding. Significantly, the type of dimer formed through the H-L-H interaction can determine the affinity, and possibly the specificity, of DNA binding (Benezra et al. 1990; Davis et al. 1990; Ellis et al. 1990). A tentative consensus DNA-binding sequence (-CA-.TG-) based on MyoD, E12/47, and yeast CBF-1 binding sites has been derived (see Cai and Davis 1990).

\section{Zipper proteins}

Another structurally significant region present in Myc family members is the "leucine zipper": a 20- to 30-residue-long amphipathic $\alpha$-helix with a leucine residue situated at every second helical turn (i.e., every 7 residues)
(Landschulz et al. 1988). This results in an array of hydrophobic leucine side chains projecting from one face of the helix. The hydrophobic faces of two such helices, arranged in parallel, appear to associate as a coiled-coil in much the same manner as intermediate filament proteins (O'Shea et al. 1989a). Zipper motifs have been identified in N-Myc, L-Myc, and c-Myc as well as in GCN4, the Jun, Fos, and ATF families, and several other DNA-binding transcription factors (see Vinson et al. 1989 and references therein), although they are likely to also function more generally in other proteins that oligomerize. It is becoming increasingly clear that the interaction between zippers can be highly specific and that this specificity is likely to reside within the zipper itself (O'Shea et al. 1989b).

The function of the zipper as a protein-protein interaction domain appears in many cases to be closely coupled to a DNA-binding activity. This is specified by a helical stretch of basic residues separated from the zipper by a 6-residue "linker" (Agre et al. 1989). It has been proposed that the interacting zipper regions within the dimer position the adjacent basic regions to form a contact surface that can bind symmetric DNA sequences (Vinson et al. 1989). In this sense, the architecture is superficially similar to that of the BR-H-L-H region mentioned above where protein-protein interaction regions (the H-L-H motif) are also thought to position the adjacent basic stretches (Davis et al. 1990). Indeed, recent experiments employing synthetic BRzipper-peptides indicate that under certain conditions the entire zipper interaction can be replaced by an S-S bond without loss of the BR DNA-binding specificity, and that specific binding to DNA induces the BR to assume a helical conformation (O'Neil et al. 1990; Talanian et al. 1990). 


\section{Myc structure}

Figure 2 diagrams the structure of $\mathrm{c}-\mathrm{Myc}$ indicating major landmarks. In c-Myc, N-Myc, and L-Myc, the region of BR-H-L-H homology (see Fig. 1) covers a block of $\sim 55$ amino acids located $\sim 30$ residues before their carboxyl termini. The remaining 30 carboxy-terminal amino acids possess the leucine spacing and $\alpha$-helical potential characteristic of the zipper motif (Landschulz et al. 1988). Having established these potential structural similarities, the obvious question is what do they mean for Myc? The presence of the BR-H-L-H-Zip makes it difficult to escape the conclusion that Myc must participate in the kinds of interactions predicated for the H-L-H and zipper proteins described above. Therefore, these structural homologies have tended to focus research on Myc toward questions concerning potential protein and DNA interactions and to give confidence to those who like to think of Myc as a transcription factor.

The excitement, however, is muted by several facts, including the inability thus far to demonstrate specitic DNA binding or to find conclusive evidence for the ability of Myc to form homotypic and/or heterotypic complexes. In addition, although $\mathrm{Myc}$ has long been known to bind nonspecifically to DNA, recent work suggests that the major region of Myc responsible for nonspecific DNA binding does not even lie within the carboxy-terminal region but comprises a large internal domain (see Fig. 2; Dang et al. 1989a). Furthermore, the Myc protein family does not fit all that neatly into the $\mathrm{H}-\mathrm{L}-\mathrm{H}$ or zipper categories for the simple reason that it contains both domains: a basic region followed by a $\mathrm{H}-\mathrm{L}-\mathrm{H}$ contiguous with a zipper, all at the carboxyl terminus of the protein (see Fig. 1). Very recently, reports have begun to appear describing other proteins containing the two motifs. All of these are transcription factors and include two proteins that bind the immuno- globulin $\mu E 3$ motif, TFE3 (Beckmann et al. 1990) and TFEB (Carr and Sharp 1990), as well as USF (Gregor et al. 1990) and AP4 (Hu et al. 1990). For USF and AP4, deletion analyses indicate that both an intact zipper and $\mathrm{H}-\mathrm{L}-\mathrm{H}$ region are required for dimer formation and DNA binding, indicating that both domains are functional (Gregor et al. 1990; Hu et al. 1990).

For $\mathrm{Myc}$, it is at least clear that the H-L-H and zipper homology regions are important. Extensive deletion and insertion mutagenesis studies with human c-Myc have shown these regions to be critical in terms of cotransformation of primary rat embryo fibroblasts, direct transformation of the Rat-1A cell line (Stone et al. 1987), negative regulation of its own expression (Crouch et al. 1990; Penn et al. 1990c; see below), and inhibition of preadipocyte (Freytag et al. 1990) and murine erythroleukemia (MEL) cell (Smith et al. 1990) differentiation. In addition, point mutations and deletions that would be expected to disrupt the leucine zipper have been demonstrated to abolish transforming function for both N-Myc and c-Myc (Nakajima et al. 1989; Crouch et al. 1990), although a small deletion at the very carboxyl terminus of c-Myc impaired but did not completely abolish transformation (Crouch et al. 1990). Furthermore, a small deletion in the zipper apparently leads to an uncoupling of the transforming specificities of $\mathrm{v}-\mathrm{Myc}$ for chicken macrophages and fibroblasts (Enrietto 1989). Finally, if the carboxy-terminal region of Myc is involved in proteinprotein interactions in vivo, one might predict that mutations lying outside of this region would permit formation of inactive complexes, that is, act as dominant negatives. This turns out to be the case for both c-myc and $\mathrm{N}$-myc mutants when tested against the wild-type gene in a cotransformation assay with activated ras (Ueno et al. 1988; Dang et al. 1989b). Taken together, these data make a good case for the importance of the carboxy-terminal 100 residues of Myc family proteins.

Given that these segments of Myc are critical for

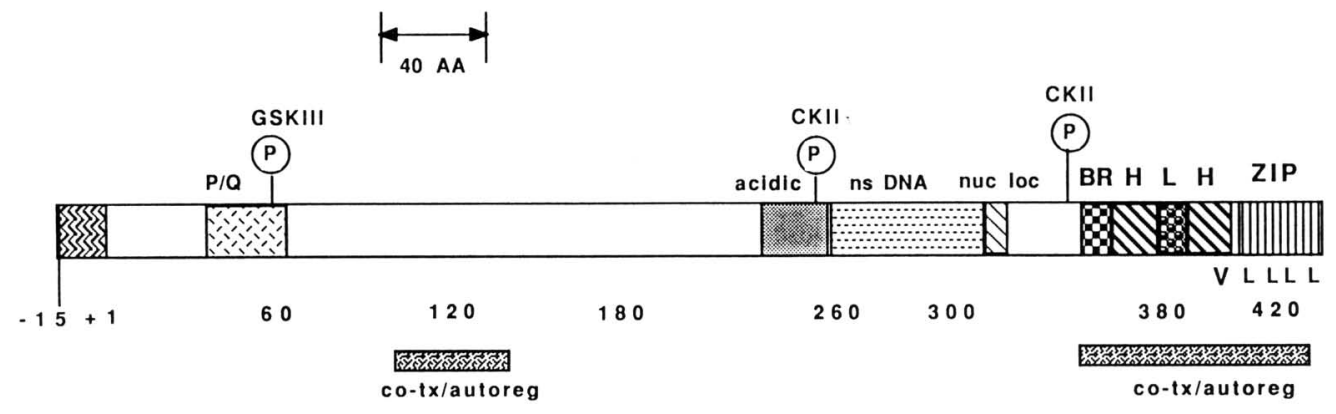

Figure 2. Landmarks in the human c-Myc protein. (BR-H-L-H-Zip) Carboxy-terminal location of the putative BR-H-L-H-zipper domain is shown (see sequences in Fig. 1). The heptad leucine repeat is indicated below the diagram; note that the valine, which may be part of the repeat, is also incuded in the helix II region. (P) Phosphorylations introduced by casein kinase II (CKII) (Lüscher et al. 1989) or glycogen synthase kinase III (GSKIII) (B. Lüscher, unpubl.); (nuc loc) nuclear localization signal, a second, weaker signal is located within the BR (Dang and Lee 1988); (nsDNA) region involved in nonspecific DNA binding (Dang et al. 1989a); (acidic) highly acidic region located at the exon 1 and 2 boundary; (P/Q) proline- and glutamine-rich segment. At the amino terminus, a 15-aminoacid-long segment is indicated as an amino-terminal extension found in $\sim 20 \%$ of the mammalian c-Myc proteins synthesized. This arises from a translational initiation at a CUG codon in exon 1 which is upstream and in-frame with the major initiating AUG in exon 2 (Hann et al. 1988). No functional difference has been found between the two Myc proteins. The bars marked co-tx/autoreg indicate the regions where deletions or mutations have been shown to abolish cotransformation with activated ras and autoregulation. 
function, is there any direct evidence that they are involved in protein-protein interactions and DNA binding? There is one report identifying a stable highmolecular-weight protein associated with Myc (Gillespie and Eisenman 1989). In addition, overexpressed Myc has been observed in large ribonucleoprotein granules (Spector et al. 1987). However, both of these associations are difficult to detect in cases when Myc is not highly overexpressed, and in neither case has progress been made in further characterization of the interacting component or of the region of Myc required for the interaction. A worry here is that overexpression might lead to adventitious nonfunctional associations. There has also been a report demonstrating formation of homodimers and tetramers at relatively high concentrations of purified bacterially expressed c-Myc (Dang et al. $1989 \mathrm{~b})$. Deletions of the zipper region appeared to prevent oligomer formation. However, another group has failed to find evidence for homodimer formation using in vitro-translated c-Myc (Smith et al. 1990). Recently, many groups have also attempted to detect interaction between Myc and proteins carrying zippers or $\mathrm{H}-\mathrm{L}-\mathrm{H}$ regions (including USF, which has both) after in vitro translation. The results appear to be uniformly negative (B. Lüscher and R.N. Eisenman, unpubl.). Thus, at least under conditions where Fos and Jun or MyoD and E12 dimerize, Myc does not appear to associate with any of these proteins.

Despite the formidable array of negative findings, very recent, and as yet unpublished, experiments may provide some cause for hope. Two laboratories have now identified a specific DNA-binding site for c-Myc homodimers. In one case, the sequence was identified by replacing the E12 BR with the c-Myc BR, allowing the E12 $\mathrm{H}-\mathrm{L}-\mathrm{H}$ framework to drive dimerization, and testing binding to oligonucleotides based on the CA-TG consensus (G. Prendergast and E. Ziff, in prep.). Another group used relatively high concentrations of a c-Myc protein fragment containing the carboxy-terminal $\mathrm{BR}-\mathrm{H}-\mathrm{L}-\mathrm{H}-\mathrm{Zip}$ region in reiterative selection and amplification of partially randomized oligonucleotides (Blackwell et al. 1990; for method, see Blackwell and Weintraub 1990|. These different approaches both led to CACGTG as a specific binding site. This sequence is apparently bound by homodimerized c-Myc BRs, which, as mentioned, are not readily formed. Thus, one can predict that c-Myc must have another partner that would heterodimerize and bind this or other DNA sequences with high affinity. A potential candidate for this role has now been identified by screening a protein expression library with the c-Myc BR-H-L-H-Zip fragment. This protein, dubbed Max, also possesses a BR-H-L-H-Zip domain and binds to c-Myc in a manner that depends on the integrity of the c-Myc carboxyl terminus (E. Blackwood and R.N. Eisenman, unpubl.). While the DNAbinding activity of the Myc/Max complex has not yet been tested, it seems that these findings may provide a handle for understanding the major molecular interactions mediated by the BR-H-L-H-Zip region of c-Myc.

\section{Activation of gene expression by Myc}

If Myc functions as a transcriptional activator, then it would be expected to stimulate a target promoter in a standard trans-activation assay, provided that one supplied the correct nucleotide-binding sequence. Early experiments along these lines produced somewhat variable c-Myc-induced activation of the hsp70 promoter and repression of the metallothionein promoter (Kingston et al. 1984; Kaddurah-Daouk et al. 1987). Other studies indicated that the adenovinus $\mathrm{E} 4$ promoter could be transactivated by Myc through the same promoter region required for Ela activation (Onclercq et al. 1988); that several "early response genes" could be activated following induced c-myc expression (although two of these are normally expressed prior to c-myc induction in mitogenic stimulation) (Schweinfest et al. 1988), and that the expression of the plasminogen activator inhibitor-1 (PAI-1) gene is increased by c-myc (Prendergast and Cole 1989|. Recently, using a c-Myc-steroid receptor fusion protein that permits hormone-dependent Myc activity (Eilers et al. 1989), a Myc-inducible transcript has been identified which is related to the $\alpha$-prothymosin gene (M. Eilers and J.M. Bishop, in prep.). Of particular interest is the fact that induction of the $\alpha$-prothymosin RNA can occur in the absence of protein synthesis, suggesting, but not formally proving, that active Myc may be directly involved in production of the transcript. However, in none of these cases has it been demonstrated that Myc binds directly to a DNA sequence involved in the activation. As described below, there is also increasing evidence for the involvement of Myc in repression of gene expression.

\section{Autoregulation of Myc expression}

In Burkitt's lymphomas and murine plasmacytomas, all or part of the c-myc locus is frequently translocated to another chromosome where its expression is presumed to be deregulated by being brought under the control of heavy- or light-chain immunoglobulin regulatory regions. However, the other c-myc allele, which is neither rearranged nor translocated, is not expressed (for review, see Cory 1986). One interpretation is that c-myc is normally transcriptionally silent at the stage of differentiation characteristic of these tumors, but the rearrangement has forced the translocated allele to be expressed. Another possibility is that c-myc is involved in a negative autoregulatory loop and that the deregulated expression of the translocated allele has caused the normal allele to shut down (Leder et al. 1983; Rabbits et al. 1984; Adams et al. 1985).

Although more recent work has indicated that the mechanism of suppression of the unrearranged allele in Burkitt's lymphomas is quite complex and may not be due to autoregulation (Siebenlist et al. 1984; Nishikura and Murray 1988; Eick and Bornkamm 1989), numerous groups have attempted to test the autoregulation model in other systems, often with varied and controversial results. For example, introduction of exogenous c-myc or 
$\mathrm{v}$-myc into different established cell lines failed to abrogate RNA expression from the endogenous gene (Keath et al. 1984; Cory et al. 1987; Zerlin et al. 1987), while in other experiments down-regulation of the endogenous gene was observed (Rapp et al. 1985; Cory et al. 1987; Dean et al. 1987; Cleveland et al. 1988). Particularly compelling are studies in transgenic mice expressing c-myc under the control of an immunoglobulin enhancer: Early B-cell populations from the bone marrow of mice expressing the transgene were clearly negative for expression of the endogenous c-myc gene, compared to control cells, although the absolute levels of transgene expression did not appear much higher than normal (Alexander et al. 1987). Furthermore, when different cell types were transfected with c-myc driven by viral promoters, or when c-myc under control of an inducible promoter was allowed to be expressed, the degree of repression of the endogenous gene appeared to be inversely proportional to the expression of the introduced c-myc, with down-regulation occurring in the Myc concentration range usually found in normal cells (Lombardi et al. 1987; Crouch et al. 1990; Grignani et al. 1990; Penn et al. 1990b). In a survey of different cell types, it appeared that primary cells and many established cell lines are highly likely to have their resident c-myc genes downregulated by an introduced deregulated myc. In contrast, most transformed cells appear resistant to autoregulation (Grignani et al. 1990). These differences may go a long way toward explaining the discrepancies in the results of the initial experiments testing the autoregulation model. They also raise the interesting possibility that the capacity to down-regulate its own expression may be an intrinsic property of Myc and that escape from such autoregulation may be linked in some manner with immortalization and transformation.

In this regard it is important to note that the Myc family proteins are also interconnected through the autoregulation mechanism. In both tumors and transfected cell lines expressing high levels of N-myc, the levels of c-myc expression are diminished markedly (Nisen et al. 1986; Cleveland et al. 1988). Furthermore pre-B cells from transgenic mice expressing deregulated $\mathrm{N}-m y c$ also show turnoff of endogenous c-myc (Dildrop et al. 1989; Rosenbaum et al. 1989). As in the case for c-myc autoregulation, $\mathrm{N}-m y c$ cross-regulation of $\mathrm{c}-\mathrm{myc}$ requires high-level expression of N-myc (Dildrop et al. 1989; Rosenbaum et al. 1989). Interestingly, in normal early Bcell development, both endogenous $\mathrm{N}-m y c$ and c-myc genes appear to be expressed at basal levels (Zimmerman et al. 1986), indicating that their coexpression is probably not incompatible under normal circumstances.

What is the mechanism of Myc autosuppression? In the first place, it is clear that introduction of an intact exogenous Myc protein is required for down-regulation (Cleveland et al. 1988) and that mutations in conserved regions important for cotransformation with ras, most notably the H-L-H and zipper domains, are sufficient to abolish the effect (Crouch et al. 1990; Penn et al. 1990c). In several cases it has been shown that down-regulation of c-myc after introduction of $\mathrm{v}-m y c$ or exogenous $c-m y c$ is due to inhibition of transcription initiation of the endogenous gene (Cleveland et al. 1988; Penn et al. 1990b). These results naturally open the question of whether Myc might bind and regulate its own promoter. Although one group has argued that this is indeed the case (Ariga et al. 1989), this conclusion has been controversial (see below). Whether or not Myc acts directly, there is now evidence indicating that it does not act alone. Analysis of hybrids between cells that do and do not autoregulate indicate that the autoregulation phenotype is dominant (Penn et al. 1990b). Assuming that Myc itself is not altered in the nonautoregulated cells, there must be other trans-acting factors present that mediate the suppression. It is worth noting that c-Fos also autoregulates its own expression through its carboxy-terminal domain. This region is deleted in v-Fos, resulting in loss of autoregulation with no effect on trans-activation (Sassone-Corsi et al. 1988; Wilson and Treisman 1988; Lucibello et al. 1990; R. Ofir et al., in prep.). In contrast, c-myb is apparently not autoregulated (Lipsick 1987). For Myc, both the normal and oncogenically activated forms appear capable of autoregulation, and mutations affecting transforming function also affect autoregulation (Crouch et al. 1990; Penn et al. 1990c). It seems likely that what is important in Myc-induced transformation is not suppression of $\mathrm{c}$-myc itself but suppression of other gene targets.

\section{Myc influences expression of other cellular genes}

In early experiments testing c-myc in trans-activation assays, both activation and repression were observed, depending on the reporter gene construct used, although the effects were of low level and rather variable / Kaddurah-Daouk et al. 1987). High-level Myc expression has also been linked to suppression of several important cell-surface molecules. Down-regulation of class I MHC (major histocompatibility antigen) and leukocyte function antigen (LFA-1) has been observed following transfection of N-myc or c-myc (Bernards et al. 1986; Versteeg et al. 1988, 1989; Lenardo et al. 1989; Inghirami et al. 1990). In addition, neural cell adhesion molecule (NCAM) has also been reported to be repressed by N-Myc (Akeson and Bernards 1990). The degree of suppression correlates inversely with the level of Myc expression, much as in the autoregulation experiments, but is rarely complete and may depend on the cell type and on whether the cell is transformed (Bernards et al. 1986). However, the suppressive effects of Myc are not simply a by-product of transformation because a series of other oncogenes had no effect on LFA-1 expression (R. DallaFavera, pers. comm.). Only the adenovirus E1A protein has been previously shown to suppress MHC class I in transformants (Schrier et al. 1983).

Another interesting case of Myc-induced suppression has been found for the $\mathrm{H}^{\circ}$ and $\mathrm{Hl}$ variant histones. 
These genes are usually expressed early after MEL cells are induced to differentiate. Differentiation of such cells can be blocked by constitutive expression of either Myc or Myb. However, only in the cells blocked with Myc are the variant histone genes not expressed /Cheng and Skoultchi 1989), consistent with the idea that unregulated Myc expression may block an earlier event in differentiation than does unregulated expression of $\mathrm{Myb}$ (Cheng and Skoultchi 1989; McClinton et al. 1990).

Some initial findings address the mechanism by which Myc may mediate suppression of cell-surface antigen expression. Binding of the nuclear factor H2TF1 to the $\mathrm{H} 2 \mathrm{~K}^{\mathrm{b}}$ enhancer is eliminated in cells where high levels of $\mathrm{N}$-myc suppress $\mathrm{H} 2-\mathrm{K}^{\mathrm{b}}$ expression (Lenardo et al. 1989). N-Myc does not interact directly with H2TF1, and preliminary experiments indicate that factor binding may be inhibited by a post-translational modification (R. Bernards, pers. comm.). In the case of LFA-1, the level of the $\alpha_{1}$-chain, mRNA is decreased. In the absence of $\alpha_{1}$, the LFA-1 tetramer is not assembled and neither the $\alpha_{1}$ nor $\beta_{2}$ subunits appear on the cell surface. When assayed during a time course of Myc induction, the rapid drop in $\alpha_{1}$ mRNA appears to be due primarily to a post-transcriptional mechanism, possibly involving transport or processing. This post-transcriptional repression precedes the decrease in gene transcription characteristic of the long-term response to Myc (Inghirami et al. 1990). A short-term post-transcriptional mechanism has also been observed for the induction of the plasminogen activator inhibitor gene by c-myc (Prendergast and Cole 1989).

Whatever the exact mechanism by which Myc mediates supression, it is likely that down-regulation of these surface proteins has profound biological consequences. Transfection of N-myc into a rat neuroblastoma cell line increases both growth rate and metastasis in nude mice (Bernards et al. 1986) and, as mentioned above, suppression of class I MHC and N-CAM has been observed in these cells (Lenardo et al. 1989; Akeson and Bernards 1990), consistent with previous findings that in human neuroblastomas $\mathrm{N}-$ myc levels correlate with metastatic potential (Brodeur et al. 1984; but see Dahllöf 1990). It has also been shown that cell migration can be affected by N-CAM expression (Thiery et al. 1982). Furthermore, reduction of LFA-1 levels in c-myc- and $\mathrm{N}$-myc-transfected lymphoblastoid cell lines has been demonstrated to correlate with dramatic decreases in cytotoxic T-cell killing in autologous assays (R. DallaFavera, pers. comm.). These findings raise the possibility that myc-induced suppression of gene expression may play a role in tumorigenesis at several levels. It is important to keep in mind that these effects may not be the result of normal Myc function but may rather represent the function of overexpressed and possibly mutated Myc. Nonetheless, the changes in expression of LFA-1, $\mathrm{N}-\mathrm{CAM}$, and MHC cell-surface proteins and other gene products by Myc family proteins may provide a molecular handle for understanding how Myc can influence cell physiology.

\section{DNA replication}

Although there is a large and transient induction of c-myc expression within hours after mitogenic stimulation of quiescent cells (Campisi et al. 1984; Kelly et al. 1983; Greenberg and Ziff 1984), the predominant mode of $\mathrm{c}-\mathrm{myc}$ expression in proliferating cells is continuous synthesis and rapid degradation throughout interphase (Hann et al. 1985; Rabbitts et al. 1985). The strong correlation between proliferation and expression of c-myc has made the possibility of the involvement of Myc in DNA replication rather attractive. While the early burst of Myc that occurs long before the onset of $S$ phase is unlikely to play a direct role in DNA replication, the basal level of c-myc expression could potentially influence replication. A number of studies have been carried out to test this idea by attempting to inhibit or enhance c-myc expression and then gauge the effects on entry into $S$ phase. Although some of the earliest experiments showed that introduction of antibodies against Myc appeared to inhibit DNA synthesis (Studzinski et al. 1986), later work demonstrated these results to be artifactual (Gutierrez et al. 1987, 1988). In another experimental approach, production of Myc was inhibited in human $\mathrm{T}$ lymphocytes by treatment with antisense oligodeoxynucleotides complimentary to the $\mathrm{c}-\mathrm{myc}$ region containing the major translational initiation codon. When such cells were mitogenically stimulated they failed to enter $S$ phase but appeared to enter and traverse $G_{1}$ normally (Heikkila et al. 1987). Other experiments, using HL60 cells, also indicated that introduction of $c-m y c$ antisense oligonucleotides resulted in a cessation of proliferation (Holt et al. 1988). These experimental results are consistent with the notion that c-Myc might be involved in replication but leave it unclear as to where Myc acts. Some very recent experiments indicate that the $S$ phase is only inhibited if Myc is suppressed within $6 \mathrm{hr}$ after entry into $G_{1}$ (Y. Yegorov, L. Lyne, C. Cremisi, and N. Sullivan, in prep.).

Several groups have sought evidence for direct involvement of Myc in replication. Since cells expressing higher levels of $c-m y c$ appear to support replication of SV40 DNA more efficiently (Classon et al. 1987), it seemed possible that an SV40 replication origin-based in vitro DNA synthesis system could provide an assay. Experiments testing a large number of different anti-Myc antibodies in the reaction have failed to find any effect on initiation of SV40 DNA replication or DNA synthesis at cellular replication forks (Gutierrez et al. 1987, 1988; J. Roberts, unpubl.). Over the last 4 years, one group has published a series of papers concluding that c-Myc can bind and promote replication at replication origins in both SV40 and c-myc itself. In addition, this putative $c-m y c$ origin also contains a transcriptional enhancer activity, suggesting that $\mathrm{c}-\mathrm{Myc}$ protein may regulate its own expression (Iguchi-Ariga et al. 1987, 1988; Ariga et al. 1989). There is ample precedent for transcription factors functioning at origins of replication (for review, see DePamphilis 1988), and this work raises the 
highly appealing possibility that Myc might function in both transcription and replication. However, these findings on Myc have not gained widespread acceptance. Other attempts to demonstrate an effect of Myc on either the SV40 origin or the mouse autonomous replicating sequence (ARS) described above have failed (Gutierrez et al. 1987, 1988), and several laboratories have not been able either to verify that the putative c-myc ARS has origin activity (M. Lipp, pers. comm.), that a c-myc origin exists at that site (McWhinney and Leffak 1990 ), or that c-Myc protein specifically binds to the origin/enhancer (L. Kretzner and E. Blackwood, unpubl; C. Dang and M. Lipp, pers. comm.). Therefore, the question of whether Myc can act directly at replication origins remains unresolved.

If Myc function is required for DNA replication, then one might expect to find a correlation between Myc expression and cell proliferation. To a certain extent this appears to be true: Cells constitutively expressing high levels of Myc have reduced growth factor requirements (Armelin et al. 1984; Sorrentino et al. 1986; Stern et al. 1986; Langdon et al. 1988), have increased growth rate (Palmieri et al. 1983; Langdon et al. 1988), spend less time in $G_{1}$ (Karn et al. 1989), and, in some cases, can circumvent growth arrest (Kohl and Ruley 1987). Conversely, Myc expression is down-regulated upon terminal differentiation of numerous cell types (for review, see Cole 1986). Since forced expression of c-Myc (and, in one case, L-Myc) blocks differentiation in erythroid, lymphoid, neural, and adipocyte cell types, and introduction of antisense vectors to turn Myc off promotes differentiation (Langdon et al. 1986; Maruyama et al. 1987; Freytag 1988; Holt et al. 1988; Kume et al. 1988; Birrer et al. 1989), it would seem that Myc is not simply a passive bystander but is directly involved in a proliferation/differentiation switch. More recently, treatment of keratinocytes with the growth inhibitor transforming growth factor- $\beta 1$ (TGF- $\beta 1$ ) has also been shown to reduce c-myc expression in a manner that suggests some involvement with the $\mathrm{Rb}$ protein (Pietenpol et al. 1990).

However, there are potentially telling exceptions to the simple correlation between myc expression and proliferation. For example, the levels of c-myc RNA and protein remain unaltered during differentiation of keratinocytes (Dotto et al. 1986; B. Lüscher, unpubl.), suggesting that myc expression is not totally incompatible with differentiation. Furthermore, over the last several years more detailed studies have appeared that point to some dissociation between proliferation and Myc expression during embryonic development in murine, avian, and amphibian systems. The results of this work defy simple summary but generally it seems that, as expected, many proliferating embryonic tissues, particularly mesoderm (e.g., in the midgestation mouse embryo and in early chicken, quail, and Xenopus embryos) show high levels of c-myc and $\mathrm{N}-\mathrm{myc}$ expression (King et al. 1986; Taylor et al. 1986; Downs et al. 1989; Jaffredo et al. 1989; Schmid et al. 1989; Sawai et al. 1990). N-myc and c-myc are expressed in the mouse embryo in distinct but frequently overlapping patterns throughout the gastrula (Downs et al. 1989; also see Zimmerman et al. 1986), and in both mouse and chicken embryos there was some evidence for subspecialization of mesoderm, in the sense that higher levels of $\mathrm{N}-m y c$ were observed in some regions (Downs et al. 1989; Sawai et al. 1990). In some cases, a clear down-regulation of myc expression could be seen to accompany differentiation in the gastrulating mouse embryo; for example, c-myc levels decreased during differentiation of extraembryonic stromal cells, and $\mathrm{N}-\mathrm{myc}$ levels were greatly reduced following differentiation of mesoderm into epithelioid cells /see Downs et al. 1989; Schmid et al. 1989). However, some of the most rapidly dividing cells (e.g., those comprising the primitive ectoderm in 7.5-day mouse embryos; avian and Xenopus endoderm) display very low or no c-myc expression while postmitotic avian neurons express c-myc (King et al. 1986; Houdry et al. 1988; Downs et al. 1989; Jaffredo et al. 1989). Thus, the expression of myc is not always tightly linked to cell proliferation.

Perhaps one of the most interesting observations concerning developmental expression of c-myc in relation to DNA replication concerns the subcellular redistribution of the c-Myc protein during early Xenopus embryogenesis (Gusse et al. 1989). Late-stage Xenopus oocytes contain an abundant store of c-Myc, which at first glance would seem to constitute another example of dissociation between replication and the presence of c-Myc. However, unlike the nuclear localized, rapidly degraded, Myc in somatic cells, the oocyte protein is largely cytoplasmic and highly stable (King et al. 1986; Taylor et al. 1986; Gusse et al. 1989|. Following fertilization, this maternal cytoplasmic store of Myc is rapidly imported into newly formed nuclei of the earliest cleavages and continues being sequestered, and presumably degraded, by the nuclei until the mid-blastula transition (MBT) (Gusse et al. 1989). The import and turnover of Myc in pre-MBT nuclei strongly suggest a functional role for c-Myc during this period. If so, then it is almost certainly not in transcription because pre-MBT embryos are transcriptionally inactive. The more likely possibility is that Myc would function in the activation of embryonic DNA replication. Indeed, the investigators point out that Myc acts much like a postulated factor, thought to be titrated by the replication machinery, whose utilization may progressively limit DNA synthesis up until the MBT (Newport and Kirschner 1984). Although this idea requires a direct test, it may well be that further study of early embryogenesis in Xenopus will provide some access to the function of Myc.

\section{Whither Myc?}

As one sorts through the vast amount of information on Myc, two things become evident. First, that while Myc function must impinge on multiple aspects of cell behavior, most of the evidence points toward it acting in transcription or DNA replication, with the possibility that it might function in both. However, as mentioned 
above, the problem with much of this work is that we cannot distinguish the direct effects from the downstream effects of Myc. Second, more biochemical characterization of $\mathrm{Myc}$ is required. The value of the $\mathrm{BR}-\mathrm{H}$ $\mathrm{L}-\mathrm{H}$ and zipper similarities is that it will concentrate research on the important questions of DNA binding and protein-protein interactions involving Myc. The tentative identification of specific c-Myc DNA-binding activity, of a protein that associates with $\mathrm{c}-\mathrm{Myc}$ through the $\mathrm{H}-\mathrm{L}-\mathrm{H}-\mathrm{Zip}$ region, and of Myc-inducible transcripts, strongly suggests, but does not prove, that Myc will be involved in transcription. If so, then the resolution of the apparent transcription versus replication dichotomy may plausibly lie in Myc being involved in transcription of genes, perhaps during early $G_{1}$, that are required for entry into $S$ phase. Alternatively, Myc might associate directly with the replication machinery through specific promoter or enhancer elements that act as auxiliary components of replication origins (see DePamphilis 1988). It seems highly likely that further delineation of the specific interactions of Myc in the cell may allow us to decide among these possibilities and eventually reward us with the elucidation of a complex biological regulatory system in molecular terms.

\section{Acknowledgments}

We are deeply grateful to our many colleagues who provided advice, unpublished information, and preprints. We also thank J. Firzlaff, A. Lassar, M. Linial, P. Neiman, and P. Whyte for critical readings of the manuscript and J. Smith for secretarial assistance. Work cited from the authors' laboratory was funded by grants from the National Cancer Institute (CA20225 and CA28151) and from the American Cancer Society.

\section{References}

Adams, J.M., A.W. Harris, C.A. Pinkert, L.M. Corcoran, W.S Alexander, S. Cory, R.D. Palmiter, and R.L. Brinster. 1985. The c-myc oncogene driven by immunoglobulin enhancers induces lymphoid malignancy in transgenic mice. Nature 318: $533-538$.

Agre, P., P.F. Johnson, and S.L. McKnight. 1989. Cognate DNA binding specificity retained after leucine zipper exchange between GCN4 and C/EBP. Science 246: 922-926.

Akeson, R. and R. Bernards. 1990. N-myc down regulates neural cell adhesion molecule expression in rat neuroblastoma. Mol. Cell. Biol. 10: 2012-2016.

Alexander, W.S., J.W. Schrader, and J.M. Adams. 1987. Expression of the c-myc oncogene under control of an immunoglobulin enhancer in Eu-myc transgenic mice. Mol. Cell. Biol. 7: 1436-1444.

Ariga, H., Y. Imamura, and S.M.M. Iguchi-Ariga. 1989. DNA replication origin and transcriptional enhancer in $\mathrm{c}-m y c$ gene share the $c-m y c$ protein binding sequences. EMBO $J$. 8: $4273-4279$.

Armelin, H.A., M.C.S. Armelin, K. Kelly, T. Stewart, P. Leder, B.H. Cochran, and C.D. Stiles. 1984. Functional role for c-myc in mitogenic response to platelet-derived growth factor. Nature 310: 655-660.

Battey, J., C. Moulding, R. Taub, W. Murphy, T. Stewart, H. Potter, G. Lenoir, and P. Leder. 1983. The human c-myc oncogene: Structural consequences of translocation into the IgH locus in Burkitt lymphoma. Cell 34: 779-787.

Beckmann, H., L.-K. Su, and T. Kadesch. 1990. TFE3: A helix- loop-helix protein that activates transcription through the immunoglobulin enhancer $\mu \mathrm{E} 3$ motif. Genes Dev. 4: 167179.

Begley, C.G., P.D. Aplan, S.M. Denning, B.F. Haynes, T.A. Waldmann, and I.R. Kirsch. 1989. The gene SCL is expressed during early hematopoiesis and encodes a differentiation-related DNA binding motif. Proc. Natl. Acad. Sci. 86: 1012810132.

Benezra, R., R.L. Davis, D. Lockshon, D.L. Turner and H. Weintraub. 1990. The protein Id: A negative regulator of helix-loop-helix DNA binding proteins. Cell 61: 49-59.

Bernards, R., S.K. Dessain and R.A. Weinberg. 1986. N-myc amplification causes down-modulation of MHC class I antigen expression in neuroblastoma. Cell 47: 667-674.

Biedenkapp, H., U. Borgemeyer, A. E. Sippel, and K.-H. Klempnauer. 1988. Viral myb oncogene encodes a sequence-specific DNA-binding activity. Nature 335: 835-837

Birrer, M., L. Raveh, H. Dosaka and S. Segal. 1989. A transfected L-myc gene can substitute for c-myc in blocking murine erythroleukemia differentiation. Mol. Cell. Biol. 9: 2734-2737.

Blackwell, T.K. and H. Weintraub. 1990. A new binding-site selection technique reveals differences and similarities between MyoD and E2A DNA-binding specificities. Science (in press).

Blackwell, T.K., L. Kretzner, E.M. Blackwood, R.N. Eisenman, and $\mathrm{H}$. Weintraub. 1990. Sequence-specific DNA binding by the c-Myc protein. Science (in press).

Brodeur, G.M., R.C. Seeger, M. Schwab, H.E. Varmus and J.M. Bishop. 1984. Amplification of $\mathrm{N}-m y c$ in untreated human neuroblastoma correlates with advanced disease stage. Science 224: 1121-1124.

Cai, M. and R.W. Davis. 1990. Yeast centromere binding protein CBF-1, of the helix-loop-helix protein family, is required for chromosome stability and methionine prototrophy. Cell 61: 437-446.

Campisi, J., H.E. Gray, A.B. Pardee, M. Dean, and G. Sonenshein. 1984. Cell cycle control of c-myc but not c-ras is lost following chemical transformation. Cell 36: 241-247.

Carr, C.S. and P.A. Sharp. 1990. A helix-loop-helix protein related to the immunoglobulin E box-binding proteins. Mol. Cell. Biol. 10: 4384-4388.

Chen, Q., J.-T. Cheng, L.-H. Tasi, N. Schneider, G. Buchanan, A. Carroll, W. Crist, B. Ozanne, M.J. Siciliano, and R. Baer. 1990. The tal gene undergoes chromosome translocation in $\mathrm{T}$ cell leukemia and potentially encodes a helix-loop-helix protein. EMBO I. 9: 415-424.

Cheng, G. and A.I. Skoultchi. 1989. Rapid induction of polyadenylated $\mathrm{Hl}$ histone mRNAs in mouse erythroleukemia cells is regulated by c-myc. Mol. Cell. Biol. 9: 2332-2340.

Classon, M., M. Henriksson, J. Sümegi, G. Klein, and M. Hammaskjöld. 1987. Elevated c-myc expression facilitates replication of SV40 DNA in human lymphoma cells. Nature 330: $272-274$.

Cleveland, J.L., M. Huleihel, P. Bressler, U. Siebenlist, L. Akiyama, R.N. Eisenman, and U.R. Rapp. 1988. Negative regulation of c-myc transcription involves myc family proteins. Oncogene Res. 3: 357-375.

Cole, M.D. 1986. The myc oncogene: Its role in transformation and differentiation. Annu. Rev. Genet. 20: 361-384.

Cory, S. 1986. Activation of cellular oncogenes in hematopoietic cells by chromosome translocation. Adv. Cancer Res. 47: 189-234.

Cory, S., O. Bernard, D. Bowtell, S. Schrader, and J.W. Schrader. 1987. Murine c-myc retroviruses alter the growth requirements of myeloid cell lines. Oncogene Res. 1: 61-76. 
Crouch, D.H., C. Lang, and D.A.F. Gillespie. 1990. The leucine zipper domain of avian c-Myc is required for transformation and autoregulation. Oncogene 5: 683-689.

Dahllöf, B. 1990. Down-regulation of MHC class I antigens is not a general mechanism for the increased tumorigenicity caused by c-myc amplification. Oncogene 5: 433-435.

Dang, C.V. and W.M.F. Lee. 1988. Identification of the human c-myc protein nuclear translocation signal. Mol. Cell. Biol. 8: $4048-4054$.

Dang, C.V., H. v. Dam, M. Buckmire, and W.M.F. Lee. 1989a. DNA-binding domain of human c-Myc produced in Escherichia coli. Mol. Cell. Biol. 9: 2477-2486.

Dang, C.V., M. McGuire, M. Buckmire, and W.M.F. Lee. 1989b. Involvement of the "leucine zipper" region in the oligomerization and transforming activity of human c-myc protein. Nature 337: 664-666.

Davis, R.L., H. Weintraub and A.B. Lassar. 1987. Expression of a single transfected cDNA converts fibroblasts to myoblasts. Cell 51: 987-1000.

Davis, R.L., P.-F. Cheng, A.B. Lassar, and H. Weintraub. 1990. The MyoD DNA binding domain contains a recognition code for muscle-specific gene activation. Cell 60: 733-746.

Dean, M.I., J.L. Cleveland, U.R. Rapp, and J.N. Ihle. 1987. Role of myc in the abrogation of IL3 dependence of myeloid FDC-P1 cells. Oncogene Res. 1: 279-296.

DePamphilis, M.L. 1988. Transcriptional elements as components of eukaryotic origins of DNA replication. Cell 52: 635-638.

DePinho, R.A., K.S. Hatton, A. Tesfaye, G.D. Yancopoulos, and F.W. Alt. 1987. The human myc gene family: Structure and activity of L-myc and an L-myc pseudogene. Genes Dev. 1: $1311-1326$.

Dildrop, R., A. Ma, K. Zimmerman, E. Hsu, A. Tesfaye, R. DePinho, and F.W. Alt. 1989. IgH enhancer-mediated deregulation of $\mathrm{N}-m y c$ gene expression in transgenic mice: Generation of lymphoid neoplasias that lack c-myc expression. $E M B O$ I. 8: $1121-1128$.

Dotto, G.P., M.Z. Gilman, M. Maruyama, and R.A. Weinberg. 1986. c-myc and c-fos expression in differentiating mouse primary keratinocytes. EMBO J. 5: 2853-2857.

Downs, K.M., G.R. Martin, and J.M. Bishop. 1989. Contrasting patterns of $m y c$ and $\mathrm{N}-\mathrm{myc}$ expression during gastrulation of the mouse embryo. Genes Dev. 3: 860-869.

Eick, D. and G.W. Bornkamm. 1989. Expression of normal and translocated c-myc alleles in Burkitt's lymphoma cells: Evidence for different regulation. EMBO J. 8: 1965-1972.

Eilers, M., D. Picard, K.R. Yamamoto, and J.M. Bishop. 1989. Chimeras of Myc oncoprotein and steroid receptors cause hormone-dependent transformation of cells. Nature 340: 66-68.

Ellis, H.M., D.R. Spann, and J.W. Posakony. 1990. extramacrochaetae, a negative regulator of sensory organ development in Drosophila, defines a new class of helix-loop-helix proteins. Cell 61: 27-38.

Enrietto, P.J. 1989. A small deletion in the carboxy terminus of the viral myc gene renders the virus MC29 partially transformation defective in avian fibroblasts. Virology 168: 256266.

Freytag, S. 1988. Enforced expression of the c-myc oncogene inhibits cell differentiation by precluding entry into a distinct predifferentiation state in G0/G1. Mol. Cell. Biol. 8: 16141624.

Freytag, S.O., C.V. Dang, and W.M.F. Lee. 1990. Definition of the activities and properties of c-myc required to inhibit cell differentiation. Cell Growth Diff. 1: 339-343.

Gillespie, D.A.F. and R.N. Eisenman. 1989. Detection of a
Myc-associated protein by chemical cross-linking. Mol. Cell. Biol. 9: 865-868.

Greenberg, M.E. and E.B. Ziff. 1984. Stimulation of 3T3 cells induces transcription of the c-fos proto-oncogene. Nature 311: 433-438.

Gregor, P.D., M. Sawadogo, and R.C. Roeder. 1990. The adenovirus major late transcription factor USF is a member of the helix-loop-helix group of regulatory proteins and binds to DNA as a dimer. Genes Dev. 4: 1730-1740.

Grignani, F., L. Lombardi, G. Inghirami, L. Sternas, K. Cechova, and R. Dalla-Favera. 1990. Negative autoregulation of c-myc gene expression is inactivated in transformed cells. EMBO $I$. (in press).

Gusse, M., J. Ghysdael, G. Evan, T. Soussi, and M. Mechali. 1989. Translocation of a store of maternal cytoplasmic c-myc protein into nuclei during early development. Mol. Cell. Biol. 9: 5395-5403.

Gutierrez, C., Z.-S. Guo, J. Farrell-Towt, G. Ju, and M.L. DePamphilis. 1987. c-myc protein and DNA replication: Separation of c-myc antibodies from an inhibitor of DNA synthesis. Mol. Cell. Biol. 7: 4594-4598.

Gutierrez, C., Z.-S. Guo, W. Burhans, M.L. DePamphilis, J. Farrell-Towt, and G. Ju. 1988. Is c-Myc protein directly involved in DNA replication? Science 240: 1202-1203.

Hann, S.R., C.B. Thompson, and R.N. Eisenman. 1985. c-myc oncogene protein synthesis is independent of the cell cycle in human and avian cells. Nature 314: 366-369.

Hann, S.R., M.W. King, D.L. Bentley, C.W. Anderson, and R.N. Eisenman. 1988. A non-AUG translational initiation in c-myc exonl generates an $\mathrm{N}$-terminally distinct protein whose synthesis is disrupted in Burkitt's lymphomas. Cell 52: 185-195.

Heikkila, R., G. Schwab, E. Wickstrom, S.L. Loke, D.H. Pluznik, R. Watt, and L.M. Neckers. 1987. A c-myc antisense oligodeoxynucleotide inhibits entry into $S$ phase but not progress from G0 to Gl. Nature 328: 445-44.

Holt, J.T., R.L. Redner, and A.W. Nienhuis. 1988. An oligomer complementary to c-myc mRNA inhibits proliferation of HL60 promyelocytic cells and induces differentiation. Mol. Cell. Biol. 8: 963-967.

Hourdry, J., A. Brulfert, M. Gusse, D. Schoevaert, M.V. Taylor, and M. Mechali. 1988. Development 104: 631-641.

Hu, Y.-F., B. Lüscher, A. Admon, N. Mermod, and R. Tjian. 1990. Transcription factor AP-4 contains multiple dimerization domains that regulate dimer specificity. Genes Dev. 4: $1741-1752$.

Inghirami, G., F. Grignani, L. Sternas, L. Lombardi, D.M. Knowles, and R. Dalla-Favera. 1990. Down-regulation of LFA- 1 adhesion receptor by the c-myc oncogene in huamn B lymphoblastoid cells. Science 250: $682-686$.

Iguchi-Ariga, S.M.M., T. Itani, Y. Kiji, and H. Ariga. 1987. Possible function of the c-myc product: Promotion of cellular DNA replication. EMBO I. 6: 2365-2371.

Iguchi-Ariga, S.M.M., T. Okazaki, T. Itani, M. Ogata, Y. Sato, and $\mathrm{H}$. Ariga. 1988. An initiation site of DNA replication with transcriptional enhancer activity present in the c-myc gene. EMBO J. 7: 3135-3142.

Jaffredo, T., B. Vandenbunder, and F. Dieterlen-Lievre. 1989. In situ study of c-myc protein expression during avian development. Development 105: 679-695.

Jones, N. 1990. Transcriptional regulation by dimerization: Two sides to an incestuous relationship. Cell 61:9-11.

Kaddurah-Daouk, R., J.M. Greene, A.S. Baldwin, and R.E. Kingston. 1987. Activation and repression of mammalian gene expression by the c-myc protein. Genes Dev. 1:347357 . 
Karn, J., J. V. Watson, A.D. Lowe, S.M. Green, and W. Vedeckis. 1989. Regulation of cell cycle duration by c-myc levels. Oncogene 4: 773-787.

Keath, E.J., P.G. Caimi, and M.D. Cole. 1984. Fiboblast lines expressing activated $\mathrm{c}-\mathrm{myc}$ oncogenes are tumorigenic in nude mice and syngeneic animals. Cell 39: 339-348.

Kelly, K., B.H. Cochran, C.D. Stiles, and P. Leder. 1983. Cellspecific regulation of the c-myc gene by lymphocyte mitogens and platelet-derived growth factor. Cell 35: 603-610.

King, M.W., J.M. Roberts, and R.N. Eisenman. 1986. Expression of the c-myc proto-oncogene during development of Xenopus laevis. Mol. Cell. Biol. 6: 4499-4508.

Kingston, R.E., A.S. Baldwin, and P.A. Sharp. 1984. Regulation of heat shock protein 70 expression by c-myc. Nature 312: 280-282.

Kohl, N.E. and H.R. Ruley. 1987. Role of c-myc in the transformation of REF52 cells by viral and cellular oncogenes. Oncogene 2: 41-48.

Kohl, N.E., E. Legouy, R.A. DePinho, P.D. Nisen, R.K. Smith, C.E. Gee, and F.W. Alt. 1986. Human N-myc is closely related in organization and nucleotuide sequence to c-myc. Nature 319: 73-77.

Kume, T.U., S. Takada, and M. Obinata. 1988. Probability that the commitment of murine erythroleukemia cell differentiation is determined by the c-myc level. J. Mol. Biol. 202: 779-786.

Landschulz, W.H., P.F. Johnson, and S.L. McKnight. 1988. The leucine zipper: A hypothetical structure common to a new class of DNA binding proteins. Science 240: 1759-1764.

Langdon, W.Y., A.W. Harris, S. Cory, and J.M. Adams. 1986. The c-myc oncogene perturbs B lymphocyte development in Eu-myc transgenic mice. Cell 47: 11-18.

Langdon, W.Y., A.W. Harris, and S. Cory. 1988. Growth of E $\mu$ myc B-lymphoid cells in vitro and their evolution towards autonomy. Oncogene Res. 3: 271-279.

Lassar, A.B., J.N. Buskin, D. Lockshon, R.L. Davis, S. Apone, S.D. Hauschka, and H. Weintraub. 1989. MyoD is a sequence-specific DNA binding protein requiring a region of myc homology to bind to the muscle creatine kinase enhancer. Cell 58: 823-831.

Leder, P., J. Battey, G. Lenoir, C. Moulding, W. Murphy, H. Potter, T. Stewart, and R. Taub. 1983. Translocations among antibody genes in human cancer. Science 222: 765-771.

Lenardo, M., A.K. Rustgi, A.R. Schievella, and R. Bernards. 1989. Suppression of MHC class 1 gene expression by $\mathrm{N}$-myc through enhancer inactivation. $E M B O /$. 8: $3351-$ 3355.

Leszczynski, J.F. and G.D. Rose. 1986. Loops in globular proteins: A novel category of secondary structure. Science 234: $849-855$.

Lipsick, J.S. 1987. v-myb does not prevent expression of c-myb in avian erythroblasts. J. Virol. 61: 3284-3287.

Lombardi, L., E.W. Newcomb, and R. Dalla-Favera. 1987. Pathogenesis of Burkitt's lymphoma: Expression of an activated c-myc oncogene causes the tumorigenic conversion of EBV-infected human B lymphoblasts. Cell 49: 161-170.

Lucibello. F.C., C. Lowag, M. Neuberg, and R. Muller. 1990. Trans-repression of mouse c-fos promoter: A novel mechanism of Fos mediated trans-regulation. Cell 59: 999-1007.

Ludwig, S.R., L.F. Habera, S.L. Dellaporta, and S.R. Wessler. 1989. $L c$, a member of the maize $R$ gene family responsible for tissue-specific anthocyanin production, encodes a protein similar to transcriptional activators and contains the myc-homology region. Proc. Natl. Acad. Sci. 86: 70927096.

Lüscher, B., E.A. Kuenzel, E.G. Krebs, and R.N. Eisenman.
1989. Myc oncoproteins are phosphorylated by casein kinase II. EMBO I. 8: 1111-1119.

Maruyama, K., S. Schiavi, W. Huse, G.L. Johnson, and E. Ruley. 1987. myc and E1A oncogenes alter the responses of PC12 cells to nerve growth factor and block differentiation. Oncogene 1: 361-367.

McClinton, D., J. Stafford, L. Brents, T.P. Bender, and W.M. Kuehl. 1990. Differentiation of mouse erythroleukemia cells is blocked by late up-regulation of a c-myb transgene. Mol. Cell. Biol. 10: 705-710.

McWhinney, C. and M. Leffak. 1990. Autonomous replication of a DNA fragment containing the chromosomal replication origin of the human c-myc gene. Nucleic Acids Res. 18: $1233-1242$.

Mellentin, J.D., C. Murre, T.A. Donlon, P.S. McCaw, S.D. Smith, A.J. Carroll, M.E. McDonald, D. Baltimore, and M.L. Cleary. 1989a. The gene for enhancer binding proteins E12/E47 lies at the $t(1 ; 19)$ breakpoint in acute leukemias. Science 246: 379-382.

Mellentin, J.D., S.D. Smith, and M.L. Cleary. 1989b. lyl-1, a novel gene altered by chromosomal translocation in $\mathrm{T}$ cell leukemia, codes for a protein with a helix-loop-helix DNA binding motif. Cell 58: 77-83.

Murre, C., P. S. McCaw, and D. Baltimore. 1989a. A new DNA binding and dimerization motif in immunoglobulin enhancer binding, daughterless, $M y o D$, and myc proteins. Cell 56: $777-783$.

Murre, C., P. S. McCaw, H. Vaessin, M. Caudy, L. Y. Jan, Y.N. Jan, C.V. Cabrera, J.N. Buskin, S.D. Hauschka, A.B. Lassar, H. Weintraub, and D. Baltimore. 1989b. Interactions between heterologous helix-loop-helix proteins generate complexes that bind specifically to a common DNA sequence. Cell 58: 537-544.

Nakajima, H., M. Ikeda, N. Tsuchida, S. Nishimura, and Y. Taya. 1989. Inactivation of the N-myc gene product by single amino acid substitution of leucine residues located in the leucine zipper region. Oncogene 4: 999-1002.

Newport, J. and M. Kirschner. 1984. Regulation of the cell cycle during early Xenopus development. Cell 37: 731-742.

Nisen, P.D., K.A. Zimmerman, S.V. Cotter, F. Gilbert, and F.W. Alt. 1986. Enhanced expression of the N-myc gene in Wilms' tumors. Cancer Res. 46: 6217-6222.

Nishikura, K. and J.M. Murray. 1988. The mechanism of inactivation of the normal c-myc gene locus in human Burkitt lymphoma cells. Oncogene 2: 493-498.

Olson, E.N. 1990. MyoD family: A paradigm for development? Genes Dev. 4: 1454-1461.

Onclercq, R., P. Gilardi, A. Lavenu, and C. Cremisi. 1988. c-myc products trans-activate the adenovirus $\mathrm{E} 4$ promoter in EC stem cells using the same target sequence as E1A products. J. Virol. 62: 4533-4537.

O'Neil, K.T., R.H. Hoess, and W.F. DeGrado. 1990. Design of DNA-binding peptides based on the leucine zipper motif. Science 249: 774-778.

O'Shea, E.K., R.H. Rutkowski, and P.S. Kim. 1989a. Evidence that the leucine zipper is a coiled coil. Science 243: $538-$ 541.

O'Shea, E.K., R.H. Rutkowski, W.S. Stafford III, and P.S. Kim. $1989 \mathrm{~b}$. Preferential heterodimer formation by isolated leucine zippers from Fos and Jun. Science 245: 646-648.

Palmieri, S., P. Kahn, and T. Graf. 1983. Quail embryo fibroblasts transformed by four v-myc containing virus isolates show enhanced proliferation but are non-tumorigenic. EMBO I. 2: 2385-2389.

Penn, L.J.Z., E.M. Laufer, and H. Land. 1990a. c-myc: Evidence for multiple regulatory functions. Sem. Cancer Biol. (in 
press).

Penn, L.J.Z., M.W. Brooks, E.M. Laufer, and H. Land. 1990b. Negative autoregulation of c-myc transcription. EMBO $/$. 9: $1113-1121$.

Penn, L.J.Z., M.W. Brooks, E.M. Laufer, T.D. Littlewood, J.P. Morgenstern, G.I. Evan, W.M.F. Lee, and H. Land. 1990c. Domains of human c-myc protein required for autosuppression and cooperation with ras oncogenes are overlapping. Mol. Cell. Biol. 10: 4961-4966.

Pietenpol, J.A., R.W. Stein, E. Moran, P. Yaciuk. R. Schlegal, R.M. Lyons, M.R. Pittelkow, K. Münger, P.M. Howley, and H.L. Moses. 1990. TGF- $\beta 1$ inhibition of c-myc transcription and growth in keratinocyutes is abrogated by viral transforming proteins with pRB binding domains. Cell 61: 777785.

Prendergast, G.C. and M.D. Cole. 1989. Post-transcriptional regulation of cellular gene expression by the c-myc oncogene. Mol. Cell. Biol. 9: 124-134.

Rabbits, T.H., A. Forster, P. Hamlyn, and R. Baer. 1984. Effect of somatic mutation within translocated c-myc genes in Burkitt's lymphoma. Nature 309: 592-597.

Rabbitts, P.H., J.W. Watson, A. Lamond, A. Forster, M.A. Stinson, G. Evan, W. Fischer, E. Athertton, M.A. Sheppard, and T.H. Rabbitts. 1985. Metabolism of c-myc gene products: c-myc mRNA and protein expression in the cell cycle. EMBO I. 4: 2009-2015.

Rapp, U.R., J.L. Cleveland, T.N. Frederickson, K.L. Holmes, H.C. Morse, H.W. Jansen, T. Patschinski, and K. Bistes. 1985. Rapid induction of homopoietic neoplasms in newborn mice by a raf (mil/myc recombinant murine retrovirus. J. Virol. 55: 23-33.

Rosenbaum, H., E. Webb, J.M. Adams, S. Cory, and A.W. Harris. 1989. N-myc transgene promotes B lymphoid proliferation, elicits lymphomas and reveals cross-regulation with $\mathrm{c}-m y c$. EMBO J. 8: 749-755.

Sassone-Corsi, P., J. C. Sisson and I. M. Verma. 1988. Transcriptional autoregulation of the proto-oncogene fos. Nature 334: 14-319.

Sawai, S., K. Kato, Y. Wakamatsu, and H. Kondoh. 1990. Organization and expression of the chicken $\mathrm{N}$-myc gene. Mol. Cell. Biol. 10: 2017-2026.

Schmid, P., W.A. Schulz, and H. Hameister. 1989. Dynamic expression of the myc protooncogene in midgestation mouse embryos. Science 243: 226-229.

Schrier, P.I., R. Bernards, R.T. M. Vaessen, A. Houweling, and A.J. van der Eb. 1983. Expression of class I major histocompatibility antigens switched off by highly oncogenic adenovirus 12 in transformed rat cells. Nature 305: 771-773.

Schweinfest, C.W., S. Fujiwara, L.F. Lau, and T.S. Papas. 1988. c-myc can induce expression of $\mathrm{G} 0 / \mathrm{G} 1$ transition genes. Mol. Cell. Biol. 8: 3080-3087.

Siebenlist, U., L. Henninghausen, J. Battey and P. Leder. 1984. Chromatin structure and protein binding in the putative regulatory region of the $\mathrm{c}-m y c$ gene in Burkitt lymphoma. Cell 37: 381-391.

Smith, M.J., D.C. Charron-Prochownik, and E.V. Prowchownik. 1990. The leucine zipper of c-Myc is required for full inhibition of erythroleukemia differentiation. Mol. Cell. Biol. 10: $5333-5339$.

Sorrentino, V., V. Drozdoff, M.D. McKinney, L. Zeitz, and E. Fleissner. 1986. Potentiation of growth factor activity by exogenous c-myc expression. Proc. Natl. Acad. Sci. 83: 81678171.

Spector, D.L., R.A. Watt, and N.F. Sullivan. 1987. The v- and c-myc oncogene proteins colocalize in situ with small nuclear ribonucleoprotein particles. Oncogene 1: 5-12.
Spencer, C.A. and M. Groudine. 1990. Control of c-myc regulation in normal and neoplastic cells. Adv. Cancer Res. (in press).

Stern, D., A. Roberts, N.S. Roche, M.B. Sporn, and R.A. Weinberg. 1986. Differential responsiveness of myc and rastransfected cells to growth factors: Selective stimulation of myc-transfected cells by epidermal growth factor. Mol. Cell. Biol. 6: 870-877.

Stone, J., T. de Lange, G. Ramsay, E. Jakobovits, J.M. Bishop, H. Varmus, and W. Lee. 1987. Definition of regions in human c-myc that are involved in transformation and nuclear localization. Mol. Cell. Biol. 7: 1697-1709.

Studzinski, G.P., Z.S. Brelvi, S.C. Feldman, and R.A. Watt. 1986. Participation of c-myc protein in DNA synthesis of human cells. Science 234: 467-470.

Talanian, R.V., C.J. McKnight, and P.S. Kim. 1990. Sequencespecific DNA binding by a short peptide dimer. Science 249: 769-771.

Taylor, M.V., M. Gusse, G.I. Evan, N. Dathan, and M. Mechali. 1986. Xenopus myc proto-oncogene during development: Expression as a stable maternal mRNA uncoupled from cell division. EMBO J. 5: 3563-3570.

Thiery, J.P., J.L. Duband, U. Rutishauser, and G.M. Edelman. 1982. Cell adhesion molecules in early chicken embryogenesis. Proc. Natl. Acad. Sci. 79: 6737-6741.

Ueno, K., K. Katoh, and H. Kondoh. 1988. Subnuclear localization and anti-transforming activity of $\mathrm{N}$-myc: $\beta$-galactosidase fusion proteins. Mol. Cell. Biol. 8: 4529-4532.

Versteeg, R., I.A. Noordermeer, M. Krüse-Wolters, D.J. Ruiter, and P.I. Schrier. 1988. c-myc down-regulates class I HLA expression in human melanomas. EMBO J. 7: 1023-1029.

Versteeg, R., M. Krüse-Wolters, A.C. Plomp, A. Van Leeuwen, N. Stam, H.L. Ploegh, D.J. Ruiter, and P.I. Schrier. 1989. Suppression of class I human histocompatibility leucocyte antigen by c-myc is locus specific. I. Exp. Med. 170: 621635.

Villares, R. and C.V. Cabrera. 1987. The achaete-scute complex of D. melanogaster: Conserved domains in a subset of genes required for neurogenesis and their homology to myc. Cell 50: $415-424$.

Vinson, C.R., P.B. Sigler, and S.L. McKnight. 1989. Scissors-grip model for DNA recognition by a family of leucine zipper proteins. Science 246: 911-916.

Weinberg, R.A. (ed.) 1989. Oncogenes and the molecular origins of Cancer. Cold Spring Harbor Laboratory Press, Cold Spring Harbor, New York.

Wilson, T. and R. Treisman. 1988. Fos C-terminal mutations block down-regulation of c-fos transcription following serum stimulation. EMBO I. 7: 4193-4202.

Zerlin, M., M.A. Julius, C. Carni, and K.B. Marcu. 1987. Elevated expression of an exogenous $\mathrm{c}-\mathrm{myc}$ gene is insufficient for transformation and tumorigenic conversion of established fibroblasts. Oncogene 1: 19-27.

Zimmerman, K.A., G.D. Yancopoulos, R.G. Collum, R.K. Smith, N.E. Kohl, K.A. Denis, M.N. Nau, Q.N. Witte, D. Toran-Allerand, C.E. Gee, J.D. Minna, and F.W. Alt. 1986. Differential expression of myc family genes during murine development. Nature 319: 780-783. 


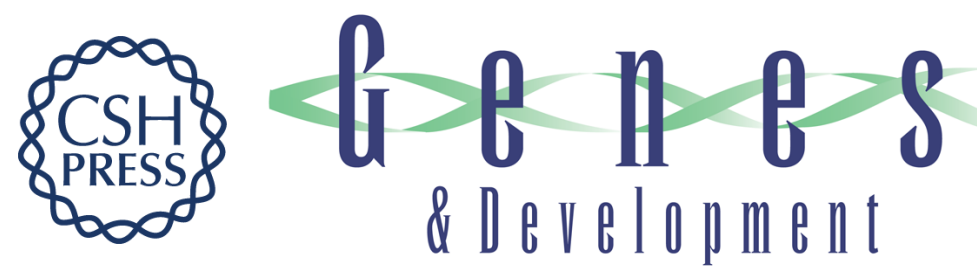

\section{New light on Myc and Myb. Part I. Myc.}

$\mathrm{B}$ Lüscher and R N Eisenman

Genes Dev. 1990, 4:

Access the most recent version at doi:10.1101/gad.4.12a.2025

References This article cites 129 articles, 56 of which can be accessed free at: http://genesdev.cshlp.org/content/4/12a/2025.full.html\#ref-list-1

License

Email Alerting

Receive free email alerts when new articles cite this article - sign up in the box at the top Service right corner of the article or click here.

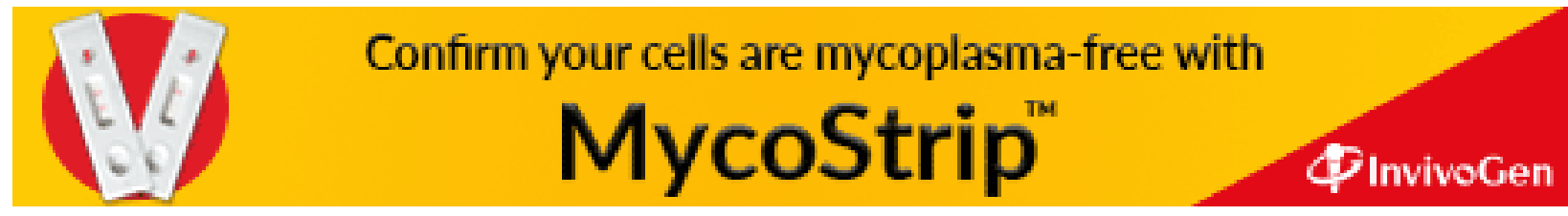

